Check for updates

Cite this: RSC Adv., 2017, 7, 26104

\title{
Adsorption of fluoride at the interface of water with calcined magnesium-ferri-lanthanum hydrotalcite-like compound
}

\begin{abstract}
Peng Wu, ${ }^{a}$ Jishan Wu, ${ }^{a}$ Ling $\mathrm{Xia}^{\mathrm{C}}{ }^{\mathrm{C}}$ Yao Liu, ${ }^{\mathrm{d}}$ Linya $\mathrm{Xu}{ }^{\mathrm{a}}$ and Shaoxian Song (iD *ab
In this work, a new adsorbent, Mg/Fe/La hydrotalcite-like compound (defined as Mg/Fe/La HLC), was synthesized with a facile one-step hydrothermal method for removing fluoride from water. Several measurements, such as XRD, FT-IR, SEM, XPS and $\mathrm{N}_{2}$ adsorption-desorption technique, were used to characterize the adsorbent and to approach into the adsorption of fluoride at the interface of water with calcined $\mathrm{Mg} / \mathrm{Fe} / \mathrm{La}$ hydrotalcite-like compound (defined as $\mathrm{Mg} / \mathrm{Fe} / \mathrm{La} \mathrm{CHLC}$ ). The experimental results have shown that the adsorption was well described by the pseudo-second-order model and followed Langmuir isotherm. The maximum adsorption capacity reached $60 \mathrm{mg} \mathrm{g}^{-1}$, and the desorption could be easily realized in a aqueous $\mathrm{Na}_{2} \mathrm{CO}_{3}$ solution, indicating that the $\mathrm{Mg} / \mathrm{Fe} / \mathrm{La} \mathrm{CHLC}$ could be used as a potential adsorbent for effectively removing fluoride from water. The mechanisms of the adsorption might be attributed to the chemisorption due to the complexation of fluoride in water with lanthanum on the surfaces of the $\mathrm{Mg} / \mathrm{Fe} / \mathrm{La} \mathrm{CHLC}$, besides of the surface adsorption and interlayer adsorption due to the "memory effect" of hydrotalcite. In addition, it was found that the element of lanthanum in the adsorbent played a great role in the adsorption of fluoride in water.
\end{abstract}

Received 19th April 2017

Accepted 8th May 2017

DOI: 10.1039/c7ra04382a

rsc.li/rsc-advances

applicability to decentralized water supply system..$^{\mathbf{1 0}}$ Numerous

\section{Introduction}

Fluoride water contamination derived from mineral weathering or chemical industry has become a worldwide concern due to its severe threat to living organisms, in particular humans. ${ }^{1}$ Longterm ingestion of high-concentration fluorides in drinking water can lead to health problems such as dental fluorosis, skeletal fluorosis and deformation of bones even lesions of the organs. ${ }^{1,2}$ Unfortunately, over 200 million people in the world are influenced by the fluoride concentrations in drinking water higher than $1.5 \mathrm{mg} \mathrm{L}^{-1}$, a guideline line set by WHO. ${ }^{3}$ Therefore, it is significant to pay attentions on fluoride removal from drinking water.

The methods for removing fluoride from water include precipitation, ${ }^{4}$ adsorption, ${ }^{5}$ electrodialysis, ${ }^{6}$ reverse osmosis, ${ }^{7}$ electrsorption $^{8}$ and membrane filtration. ${ }^{9}$ Among them, adsorption has been considered to be the superior technique for defluoridation because of its low cost, easy operation, minimized waste disposal, environment-friendliness and

${ }^{a}$ School of Resources and Environmental Engineering, Wuhan University of Technology, Luoshi Road 122, Wuhan, Hubei, 430070, China. E-mail: ssx851215@whut.edu.cn

${ }^{b}$ Hubei Key Laboratory of Mineral Resources Processing and Environment, Luoshi Road 122, Wuhan, Hubei, 430070, China

${ }^{c}$ Hubei Provincial Collaborative Innovation Center for High Efficient Utilization of Vanadium Resources, Luoshi Road 122, Wuhan, Hubei, 430070, China

${ }^{d}$ Department of Pharmacy, The First People's Hospital of Xiushui County, Jiujiang, Jiangxi, 332400, China natural or synthetic materials have been used as fluoride adsorbents, such as red mud, alum sludge, carbon nanotubes and mixed metal oxides. ${ }^{11-15}$ However, the adsorption and desorption performance was limited because of the structure of these material. It might be a good idea to use nano-scale layered materials to remove fluoride from aqueous solutions.

Layered double hydroxides (LDH), also known as hierarchical anionic clays, have attracted considerable attentions due to their case applicability such as catalysts, nanotechnology and environmental decontamination. The general formula of $\mathrm{LDH}$ can be represented as $\left[\mathrm{M}_{1-x}{ }^{2+} \mathbf{M}_{x}{ }^{3+}(\mathrm{OH})_{2}\right]\left(\mathrm{A}^{n-}\right)_{\frac{n}{x}} \cdot m \mathrm{H}_{2} \mathrm{O}$, where $\mathrm{M}^{2+}$ and $\mathrm{M}^{3+}$ represent divalent metal cations $\left(\mathrm{Mg}^{2+}, \mathrm{Ni}^{2+}, \mathrm{Cu}^{2+}\right.$, $\mathrm{Zn}^{2+}$, etc. $)$ and trivalent metal cations $\left(\mathrm{Fe}^{3+}, \mathrm{Al}^{3+}, \mathrm{Cr}^{3+}, \mathrm{La}^{3+}\right.$, etc. $)$, respectively, $x$ is the molar ratio of $\mathrm{M}^{3+} /\left(\mathrm{M}^{2+}+\mathrm{M}^{3+}\right), \mathrm{A}^{n-}$ is the intercalated anion $\left(\mathrm{CO}_{3}{ }^{2-}, \mathrm{NO}_{3}{ }^{-}, \mathrm{Cl}^{-}\right.$, etc. $)$. The positive surplus charges of the metal hydroxide layer are balanced by interlayer anions. With thermal decomposition, LDH could turn into mixed metal oxides due to the elimination of interlayer anions. The oxides could be reconstructed into their original layered structure by adsorbing various anions in aqueous solution during the rehydration process, which is termed "memory effect". ${ }^{16}$ Because of the high anion-exchange capacities and large surface area, the calcined $\mathrm{LDH}$ have been considered as effective adsorbent for removing fluoride in water. ${ }^{17,18}$

For these layered compounds, most studies focus on the aluminum-based ones such as $\mathrm{Mg} / \mathrm{Al} \mathrm{LDH.}{ }^{19,20}$ However, the 
high residual concentration of aluminum after adsorption in drinking water has been proven to be a potential risk factor for human health. ${ }^{21}$ Recently, a large amount of researches have been done to develop iron-based adsorbents for removing hazardous anions from water. ${ }^{22-24}$ In addition, rare earth metals (La, Ce, ect.) have been added into the oxides for fluoride removal, showing a strong affinity to fluoride ion due to their high electropositivity. ${ }^{25-27}$ Accordingly, introducing La into the $\mathrm{Mg} / \mathrm{Fe}$ layered compound to develop an $\mathrm{Mg} / \mathrm{Fe} / \mathrm{La}$ hydrotalcitelike compound with hierarchically porous structure might be a good adsorbent for fluoride removal from water.

In this work, a new material, $\mathrm{Mg} / \mathrm{Fe} / \mathrm{La}$ hydrotalcite-like compound, was synthesized with a facile one-step hydrothermal method, and then the $\mathrm{Mg} / \mathrm{Fe} / \mathrm{La} \mathrm{CHLc}$ was tested on the adsorption of fluoride in aqueous solutions. The objectives of this study are to develop a new and effective adsorbent for fluoride removal from water and to approach into the mechanisms of the adsorption and desorption fluoride at the interface of $\mathrm{Mg} / \mathrm{Fe} / \mathrm{La} \mathrm{HLC/water.}$

\section{Materials and methods}

\subsection{Reagents and chemicals}

All the reagents used in the study were all of analytical grade and purchased from Sinopharm Chemical Regent Co., Ltd. (China). Ultrapure water was used throughout the synthesis and adsorption experiments.

\subsection{Preparation of adsorbent}

The $\mathrm{Mg}$-Fe-La hydrotalcite-like compounds for a constant $\mathrm{Mg}^{2+}:\left(\mathrm{Fe}^{3+}+\mathrm{La}^{3+}\right)$ ratio of $3: 1$ with different $\mathrm{La}^{3+}:\left(\mathrm{Fe}^{3+}+\right.$ $\left.\mathrm{La}^{3+}\right)$ ratios were synthesized using hydrothermal method. In detail, the solution containing $\mathrm{Fe}\left(\mathrm{NO}_{3}\right)_{3} \cdot 9 \mathrm{H}_{2} \mathrm{O}, \mathrm{Mg}\left(\mathrm{NO}_{3}\right)_{2} \cdot 6 \mathrm{H}_{2} \mathrm{O}$ and $\mathrm{La}\left(\mathrm{NO}_{3}\right)_{3} \cdot 6 \mathrm{H}_{2} \mathrm{O}$ with desired amount was mixed with $50 \mathrm{~mL}$ water, and then transferred into a $100 \mathrm{~mL}$ Teflon-lined autoclave after taking ultrasonic oscillation for 10 minutes and heated at $150{ }^{\circ} \mathrm{C}$ for $12 \mathrm{~h}$ in a muffle furnace. After the furnace chamber cooled down, the precipitate was separated by the suction filter machine and washed with de-ionized water until the $\mathrm{pH}$ value was close to 7 . The wet solid was slowly dried in the oven at $70{ }^{\circ} \mathrm{C}$ for $10 \mathrm{~h}$, and finally calcined at different temperatures $\left(150,300,400,500,600,700,800{ }^{\circ} \mathrm{C}\right)$ for $3 \mathrm{~h}$ to obtain $\mathrm{Mg} / \mathrm{Fe} / \mathrm{La} \mathrm{CHLc}$. The calcined and uncalcined ones were subsequently used for adsorption experiments.

\subsection{Characterization methods}

The as-prepared $\mathrm{Mg} / \mathrm{Fe} / \mathrm{La} \mathrm{HLc}$ and $\mathrm{Mg} / \mathrm{Fe} / \mathrm{La}$ CHLc before and after fluoride adsorption were characterized by scanning electron microscopic (SEM), specific surface and pore size analysis, X-ray diffraction (XRD), Fourier transform infrared spectroscopy (FT-IR) and X-ray photoelectron spectroscopy (XPS). The surface morphology of the materials were determined by SEM operating at $20 \mathrm{kV}$ (JSM-IT300, JEOL, Japan). The phase components and crystallinity of the $\mathrm{Mg} / \mathrm{Fe} / \mathrm{La}$ materials were determined by X-ray Diffraction analysis (D8, Brucker, Germany). The specific surface area and pore structure of the samples (degassed at
$150{ }^{\circ} \mathrm{C}$ in vacuum) were conducted by nitrogen adsorptiondesorption at $77 \mathrm{~K}$ (V-Sorb2800P, Gold APP, China). FT-IR spectroscopy (2000, Thermo Nicolet, America) was used to detect the chemical bonds presented on the samples. Additionally, the functional groups and the chemical state of the element before and after adsorption were determined by X-ray photoelectron spectroscopy (XPS) (2000, Thermo Electron VG Multilab, America).

\subsection{Batch adsorption experiments}

The fluoride adsorption experiments were estimated in batch mode in terms of molar ratio of nitrate, contact time, fluoride concentration and initial $\mathrm{pH}$. The adsorption experiments except isotherm experiments were performed in triplicate with $100 \mathrm{~mL}$ initial fluoride concentration of $5 \mathrm{mg} \mathrm{L}^{-1}$ in $150 \mathrm{~mL}$ capacity PVC conical flask and added a defined amount of $\mathrm{Mg} /$ $\mathrm{Fe} / \mathrm{La} \mathrm{CHLc}$ in a mechanical shaker at the speed of $150 \mathrm{rpm}$ at $35 \pm 1{ }^{\circ} \mathrm{C}$. The adsorption isotherm experiments were obtained by adding $0.05 \mathrm{~g} \mathrm{Mg} / \mathrm{Fe} / \mathrm{La} \mathrm{CHLc}$ to $100 \mathrm{~mL}$ fluoride solutions with a concentration range of $5-130 \mathrm{mg} \mathrm{L}^{-1}$ at $\mathrm{pH} 6.8 \pm 0.1$ under $35 \pm 1{ }^{\circ} \mathrm{C}$ for $10 \mathrm{~h}$ in a mechanical shaker at the speed of $150 \mathrm{rpm} \min ^{-1}$. The effect of $\mathrm{pH}$ on the adsorption was conducted within a $\mathrm{pH}$ range of 6 to 11 and the $\mathrm{pH}$ value of the solution was adjusted by $0.1 \mathrm{~mol} \mathrm{~L}^{-1} \mathrm{NaOH}$ or $0.1 \mathrm{~mol} \mathrm{~L}^{-1} \mathrm{HCl}$ solutions. The concentration of fluoride ion was measured according to the Chinese National Standard HJ 488-2009 "Water Quality-Determination of Fluoride and Fluoride Reagent Spectrophotometric Method", in which fluoride was determined with a spectrophotometer (Orion Aquamate 8000, Thermo Fisher Scientific, America) based on the fluoride/lanthanum(III)/ alizarin mixed-ligand blue ternary complex at a wavelength of $620 \mathrm{~nm} .{ }^{28}$ And the fluoride adsorption capacity was calculated by using the following equation:

$$
q_{\mathrm{e}}=\frac{\left(c_{0}-c_{\mathrm{e}}\right) \times V}{m}
$$

where $q_{\mathrm{e}}$ is the fluoride adsorption capacity of the $\mathrm{Mg} / \mathrm{Fe} / \mathrm{La}$ CHLc $\left(\mathrm{mg} \mathrm{g}^{-1}\right), c_{0}$ is the initial fluoride concentration $(\mathrm{mg}$ $\left.\mathrm{L}^{-1}\right)$ and $c_{\mathrm{e}}$ is the fluoride ions concentration at equilibrium (mg $\mathrm{L}^{-1}$ ), respectively. $V$ is the initial volume of solution (L), $m$ is the $\mathrm{Mg} / \mathrm{Fe} / \mathrm{La} \mathrm{CHLc}$ weight used in the adsorption process $(g)$.

$$
q_{t}=\frac{\left(c_{0}-c_{t}\right) \times V}{m}
$$

where $q_{\mathrm{t}}$ and $c_{\mathrm{t}}$ is the adsorption capacity $\left(\mathrm{mg} \mathrm{g}^{-1}\right)$ and concentration $\left(\mathrm{mg} \mathrm{L}^{-1}\right)$ at time $t$, respectively.

\subsection{Desorption and regeneration}

The adsorption-desorption studies were conducted as follows: $0.5 \mathrm{~g} \mathrm{Mg} / \mathrm{Fe} / \mathrm{La} \mathrm{CHLc}$ was mixed with $1000 \mathrm{~mL} 5 \mathrm{ppm}$ of fluoride solution for $8 \mathrm{~h}$ for full adsorption. After adsorption the adsorbent was separated by filtration with $0.45 \mu \mathrm{m}$ microfiltration membrane and washed several times with deionized water. The desorption studies were carried out by adding the fluoride loaded $\mathrm{Mg} / \mathrm{Fe} / \mathrm{La}$ CHLc into $0.1 \mathrm{~mol} \mathrm{~L}^{-1} \mathrm{Na}_{2} \mathrm{CO}_{3}$ solution and the mixture was shaken for $8 \mathrm{~h}$. After desorption, the 
adsorbent was separated by filtration as above-mentioned and dried, followed by calcination in the muffle furnace for $3 \mathrm{~h}$ for further adsorption experiments. The adsorption-desorption process was repeated for 5 times and the $\mathrm{F}$ concentration in the process was measured and recorded.

\section{Results and discussion}

\subsection{Characterization of materials}

The XRD patterns of the synthesized $\mathrm{Mg} / \mathrm{Fe} / \mathrm{La} \mathrm{HLc}$ and its calcination product were shown in Fig. 1. The characteristic peaks of the $\mathrm{Mg} / \mathrm{Fe} / \mathrm{La} \mathrm{HLc} \mathrm{(Fig.} \mathrm{1a)} \mathrm{(003),} \mathrm{(006),} \mathrm{(009),} \mathrm{(015),}$ (018), (110), (115), corresponding to the diffraction peaks of

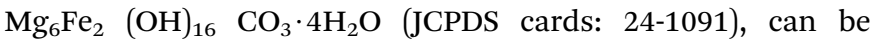
assigned to typical peaks of layered double hydroxide. ${ }^{29}$ Meanwhile, the diffraction peaks with symmetrical planes and sharp peaks demonstrated the high crystallization of $\mathrm{Mg} / \mathrm{Fe} / \mathrm{La} \mathrm{HLc}$. This was suggesting that synthesized material was hydrotalcitelike compound. However, the characteristic peaks of $\mathrm{Mg} / \mathrm{Fe} / \mathrm{La}$ CHLc disappeared in corresponding positions after calcination at $600{ }^{\circ} \mathrm{C}$ (Fig. 1b), this was attributed to that the calcined $\mathrm{Mg} / \mathrm{Fe} / \mathrm{La} \mathrm{HLc}$ formed the amorphous mixed oxides. Moreover, after adsorption of $\mathrm{F}$, as shown in Fig. 1c, the $2 \theta$ value of the characteristic peaks of $\mathrm{Mg} / \mathrm{Fe} / \mathrm{La}$ CHLc-F and $\mathrm{Mg} / \mathrm{Fe} / \mathrm{La} \mathrm{HLc}$ were utterly same, it was indicated that $\mathrm{Mg} / \mathrm{Fe} / \mathrm{La}$ CHLc possessed "memory effect".

The specific surface areas, pore volume and average pore diameter of the materials were calculated via the $\mathrm{N}_{2}$ adsorption-

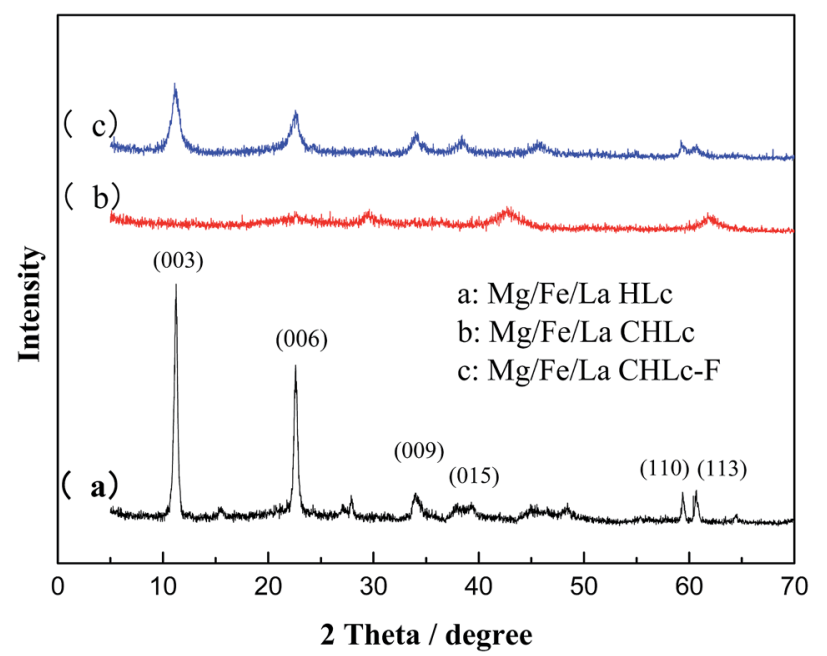

Fig. 1 XRD patterns of the Mg/Fe/La HLc (a), Mg/Fe/La CHLc calcined at $600{ }^{\circ} \mathrm{C}$ before (b) and after adsorption of $\mathrm{F}(\mathrm{c})$. desorption technique. As shown in the Table 1, the specific surface area, average pore diameter and pore volume of $\mathrm{Mg} / \mathrm{Fe} /$ La HLc were $18.7 \mathrm{~m}^{2} \mathrm{~g}^{-1}, 26.99 \mathrm{~nm}$ and $0.131 \mathrm{~cm}^{3} \mathrm{~g}^{-1}$, while the $\mathrm{Mg} / \mathrm{Fe} / \mathrm{La}$ CHLc were $59.3 \mathrm{~m}^{2} \mathrm{~g}^{-1}, 22.31 \mathrm{~nm}$ and $0.347 \mathrm{~cm}^{3} \mathrm{~g}^{-1}$, respectively. The surface area and pore volume considerably increased but the average pore diameter decreased after calcination. It revealed that $\mathrm{CO}_{3}{ }^{2-}$ in the interlayer was transformed to $\mathrm{CO}_{2}$ and the layers were destroyed during the calcination process, leading to a porous structure in the $\mathrm{Mg} / \mathrm{Fe} / \mathrm{La} \mathrm{CHLc}$. These properties provide favorable condition for fluoride removal.

The FT-IR spectra of $\mathrm{Mg} / \mathrm{Fe} / \mathrm{La}$ HLc before and after calcination were shown in Fig. 2. The broad and intense absorption band at around $3416 \mathrm{~cm}^{-1}$ was attributed to the bending vibration of the water molecule and $\mathrm{OH}$ stretching frequency in interlayer region of $\mathrm{Mg} / \mathrm{Fe} / \mathrm{La} \mathrm{HLc.}{ }^{30}$ The peaks at $2924 \mathrm{~cm}^{-1}$, $2534 \mathrm{~cm}^{-1}, 1437 \mathrm{~cm}^{-1}, 884 \mathrm{~cm}^{-1}$ and $748 \mathrm{~cm}^{-1}$ were assigned to the asymmetric stretching bands of the carbonate or bitrate radical. ${ }^{31,32}$ It is important to mention that the intensity of the $\mathrm{OH}$ and $\mathrm{CO}_{3}{ }^{2-}$ band were diminished or lost after calcination at $600{ }^{\circ} \mathrm{C}$, revealing that water molecules and $\mathrm{CO}_{3}{ }^{2-}$ were continuously removed and released from the interlayer of the oxides during the calcination. The samples showing bands in the range of $800 \mathrm{~cm}^{-1}$ to $474 \mathrm{~cm}^{-1}$ were attributed to metal-oxygen (M-O) and metal-hydroxyl ( $\mathrm{M}-\mathrm{OH})$ band vibrations. ${ }^{33}$

SEM analyses were performed on the samples to investigate the surface morphology and the results were shown in Fig. 3. It can be seen from the Fig. 3a, the morphology of $\mathrm{Mg} / \mathrm{Fe} / \mathrm{La} \mathrm{HLc}$ was dominated by homogeneous, plate-like structures with

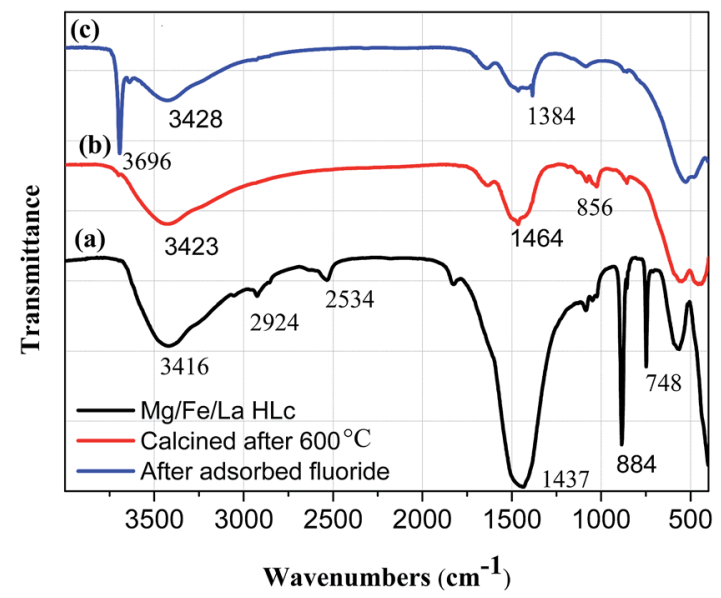

Fig. 2 FT-IR spectra of (a) Mg/Fe/La HLC, Mg/Fe/La HLC calcined at $600{ }^{\circ} \mathrm{C}$ before (b) and after (c) adsorbed fluoride.

Table 1 The BET surface area, pore volume and average pore diameter of $\mathrm{Mg} / \mathrm{Fe} / \mathrm{La} \mathrm{HLC}, \mathrm{Mg} / \mathrm{Fe} / \mathrm{La} \mathrm{CHLC} \mathrm{calcined} \mathrm{at} 600{ }^{\circ} \mathrm{C}$ before and after adsorption of fluoride

\begin{tabular}{lllllllr}
\hline Materials & $S_{\text {BET }}, \mathrm{m}^{2} \mathrm{~g}^{-1}$ & $S_{\text {mic }}, \mathrm{m}^{2} \mathrm{~g}^{-1}$ & $S_{\text {mes }}, \mathrm{m}^{2} \mathrm{~g}^{-1}$ & $V_{\mathrm{T}}, \mathrm{cm}^{3} \mathrm{~g}^{-1}$ & $V_{\text {mic }}, \mathrm{cm}^{3} \mathrm{~g}^{-1}$ & $\mathrm{~V}_{\text {mes }}, \mathrm{cm}^{3} \mathrm{~g}^{-1}$ & $D_{,} \mathrm{nm}^{-1}$ \\
\hline $\mathrm{Mg} / \mathrm{Fe} / \mathrm{La} \mathrm{HLc}$ & 18.7 & 0 & 18.7 & 0.131 & 0.006 & 0.126 \\
$\mathrm{Mg} / \mathrm{Fe} /$ La CHLc & 59.3 & 0 & 59.3 & 0.347 & 0.021 & 0.331 \\
$\mathrm{Mg} / \mathrm{Fe} /$ La CHLc-F & 27.9 & 0 & 27.9 & 0.249 & 0.0126 & 0.239
\end{tabular}




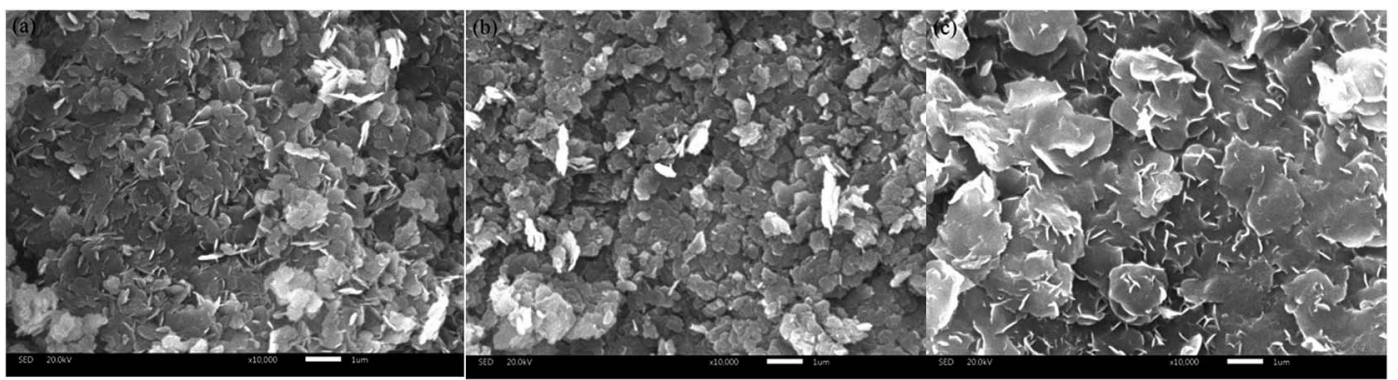

Fig. $3 \mathrm{SEM}$ images of Mg/Fe/La HLc (a), Mg/Fe/La HLc calcined at $600^{\circ} \mathrm{C}$ before (b) and after (c) adsorbed fluoride.

visible edges and smooth surface. After calcinated at $600{ }^{\circ} \mathrm{C}$, a rough surface can be obviously observed in Fig. 1b, and the material presented an irregular structure. This was due to the decomposition of hydroxides into mixed oxides and a porous structure was formed during the calcination process.

\subsection{Adsorption performance}

3.2.1 Effect of calcination temperature. The adsorption capacity of fluoride ion by $\mathrm{Mg} / \mathrm{Fe} / \mathrm{La}$ HLc calcined at different temperatures was investigated. The result presented in Fig. 4 showed that the fluoride uptake capacity by the obtained adsorbent increased significantly with the calcination temperature increasing from 150 to $600{ }^{\circ} \mathrm{C}$ and peaked at $9.5 \mathrm{mg} \mathrm{g}^{-1}$, indicating a great enhancement compared with the raw material without calcination. However, a further increase in the calcination temperature caused an obvious decrease in the fluoride adsorption. It was implied that the $\mathrm{Mg} / \mathrm{Fe} / \mathrm{La}$ mixed oxides was formed at the calcination temperature of $600{ }^{\circ} \mathrm{C}$ by losing interlayer anions and had the highest specific surface area, which is favorable for fluoride adsorption. ${ }^{34}$ However, it was transformed into a spinel and could not reconstruct the hydrotalcite-like structures leading to lose the "memory effect" and the formed pore structure may collapse when the calcination temperature is above $600{ }^{\circ} \mathrm{C}^{35}$ Thus, the $\mathrm{Mg} / \mathrm{Fe} / \mathrm{La}$

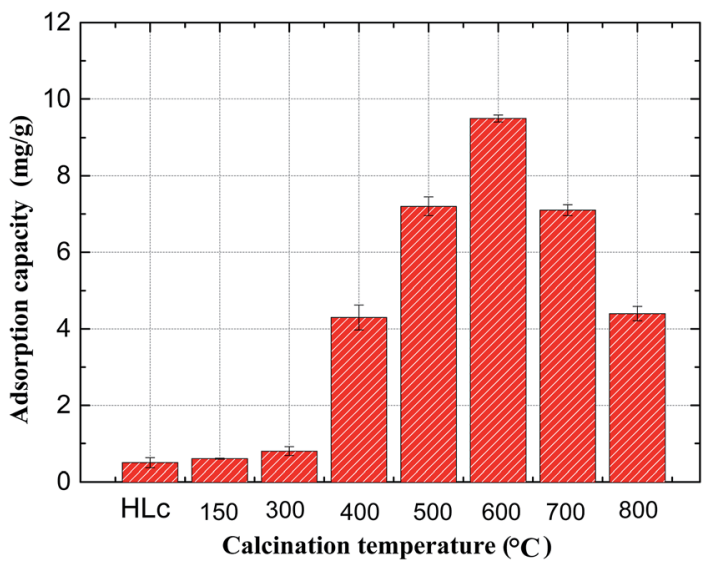

Fig. 4 Effect of calcination temperature $\left({ }^{\circ} \mathrm{C}\right)$ on the $\mathrm{Mg} / \mathrm{Fe} / \mathrm{La} \mathrm{CHLC}$ for fluoride removal (calcinations time, $3 \mathrm{~h}$; initial fluoride concentration, $5.2 \mathrm{mg} \mathrm{L}^{-1} ; \mathrm{pH}, 6.8 \pm 0.1$; adsorbent dosage, $0.3 \mathrm{~g} \mathrm{~L}^{-1}$; temperature, $35^{\circ} \mathrm{C}$; adsorption time, $10 \mathrm{~h}$ ).
CHLc calcined at $600{ }^{\circ} \mathrm{C}$ was used for the subsequent experiments.

3.2.2 Effect of $\mathrm{La}^{3+} /\left(\mathrm{Fe}^{3+}+\mathrm{La}^{3+}\right)$ molar ratio. In order to study the optimized molar ratio of the $\mathrm{Mg} / \mathrm{Fe} / \mathrm{La}$ CHLc material for fluoride removal, the materials were prepared with different $\mathrm{La}^{3+} /\left(\mathrm{Fe}^{3+}+\mathrm{La}^{3+}\right)$ molar ratios while keeping constant $\mathrm{Mg}^{2+} /$ $\left(\mathrm{Fe}^{3+}+\mathrm{La}^{3+}\right)$ molar ratio of $3: 1$. As shown in Fig. 5 , the $\mathrm{La}^{3+} /$ $\left(\mathrm{Fe}^{3+}+\mathrm{La}^{3+}\right)$ molar ratio had a significant effect on the fluoride adsorption capacity. It was obviously observed that with the increasing percentage of $\mathrm{La}^{3+}$ addition, the $\mathrm{F}$ removal efficiency first climb up and then decline. The highest capacity $(9.17 \mathrm{mg}$ $\left.\mathrm{g}^{-1}\right)$ was found at $\mathrm{La}^{3+} /\left(\mathrm{Fe}^{3+}+\mathrm{La}^{3+}\right)$ molar ratio of $1 / 10$, which was much higher than that without La addition $\left(6.87 \mathrm{mg} \mathrm{g}^{-1}\right)$, indicating that adding lanthanum to the $\mathrm{Mg} / \mathrm{Fe} / \mathrm{La} \mathrm{HLc}$ could contribute to improve the adsorption capacity of $\mathrm{Mg} / \mathrm{Fe}$ CHLc for fluoride uptake. Reasons for this enhancement can be ascribed to the stronger affinity between La and fluoride ion than Fe. ${ }^{15}$ However, the decreased uptake capacity with the further increasing percentage of La may be due to that the larger ion radius of lanthanum $(0.1032 \mathrm{~nm})$ than iron $(0.055 \mathrm{~nm})$, lead to impede the easy intercalation of $\mathrm{La}^{3+}$ in the hydrotalcites galleries. ${ }^{36}$ Considering the removal efficiency and economic cost, the molar ratio for $\mathrm{La}^{3+} /\left(\mathrm{Fe}^{3+}+\mathrm{La}^{3+}\right)$ of $1 / 10$ (corresponding to a $\mathrm{La}^{3+}$ percentage of $2.5 \%$ ) was selected for the further studies.

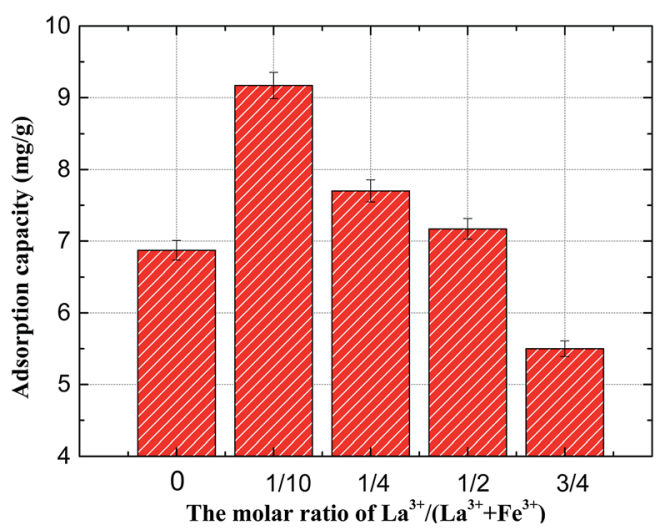

Fig. 5 Removal efficiency of fluoride ion by $\mathrm{Mg} / \mathrm{Fe} / \mathrm{La} \mathrm{CHLC}$ with different $\mathrm{La}^{3+} /\left(\mathrm{Fe}^{3+}+\mathrm{La}^{3+}\right)$ molar ratios (initial fluoride concentration, $5.2 \mathrm{mg} \mathrm{L}^{-1} ; \mathrm{pH}, 6.8 \pm 0.1$; adsorbent dosage, $0.3 \mathrm{~g} \mathrm{~L}^{-1}$; temperature, $35^{\circ} \mathrm{C}$; adsorption time, $10 \mathrm{~h}$ ). 
3.2.3 Effect of initial solution $\mathbf{p H}$. In adsorption technology, the initial $\mathrm{pH}$ in solution is an important parameter influencing the fluoride adsorption performances on medium, since it controls the interface at the adsorbent and aqueous solution. The effects of the initial $\mathrm{pH}$ on the fluoride adsorption performance by $\mathrm{Mg} / \mathrm{Fe} / \mathrm{La} \mathrm{CHLc}$ were investigated and the results were shown in Fig. 6. Obviously, the asprepared $\mathrm{Mg} / \mathrm{Fe} / \mathrm{La}$ CHLc material had a defluoridation performance within a wide $\mathrm{pH}$ range from 6 to 9 , and the optimal $\mathrm{pH}$ for fluoride sorption was found at about 6.8, with the highest capacity of $9.19 \mathrm{mg} \mathrm{g}^{-1}$. At alkaline condition, the adsorption capacity decreased when $\mathrm{pH}$ value was higher than 8 . It can be seen from Fig. 6, the Zeta potential of the adsorbent decreased with the increased of $\mathrm{pH}$ value, the surface of the material was negatively charged when $\mathrm{pH}>8$, leading to the electrostatic repulsion of $\mathrm{Mg} / \mathrm{Fe} / \mathrm{La} \mathrm{CHLc}$ to fluoride ions, namely, the adsorbent was unfavorable for the fluoride adsorption when $\mathrm{pH}>8$. The competition between fluoride ions and hydroxyl ions on the $\mathrm{Mg} / \mathrm{Fe} / \mathrm{La} \mathrm{CHLc}$ active adsorption sites in alkaline solution is another reason for the observation. After adsorption, the equilibrium $\mathrm{pH}$ of the solution increased compared to the initial $\mathrm{pH}$ value, which can be attributed to the $\mathrm{Mg} / \mathrm{Fe} / \mathrm{La}$ mixed oxides change to $\mathrm{Mg} /$ $\mathrm{Fe} / \mathrm{La}$ mixed hydroxyl during the rehydration reaction in the fluoride adsorption process.

3.2.4 Adsorption kinetic. Two kinetic models such as pseudo-first-order eqn (3), pseudo-second-order models eqn (4) were mathematically simulate the kinetics experimental data, the equations are given as:

$$
\begin{gathered}
\ln \left(q_{\left.\mathrm{e}-q_{t}\right)}=\ln q_{\mathrm{e}}-k_{1} t\right. \\
\frac{t}{q_{t}}=\frac{1}{k_{2} q_{\mathrm{e}}^{2}}+\frac{t}{q_{\mathrm{e}}}
\end{gathered}
$$

where $q_{t}$ is the amount of fluoride adsorbed $\left(\mathrm{mg} \mathrm{g}^{-1}\right)$ at time $t$, $q_{\mathrm{e}}$ is the amount of fluoride adsorbed $\left(\mathrm{mg} \mathrm{g}^{-1}\right)$ at equilibrium, $k_{1}\left(\min ^{-1}\right)$ and $k_{2}\left(\mathrm{~g} \mathrm{mg}^{-1} \mathrm{~g} \mathrm{~min}^{-1}\right)$ is the equilibrium rate constants of the kinetics model.

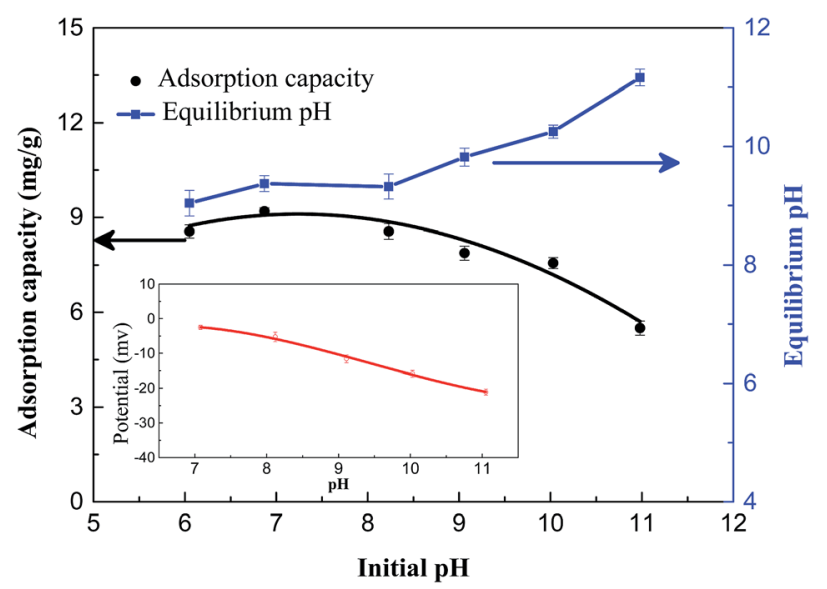

Fig. 6 Effect of initial $\mathrm{pH}$ on the adsorption of fluoride in $5.2 \mathrm{mg} \mathrm{L}^{-1}$ solutions on $\mathrm{Mg} / \mathrm{Fe} / \mathrm{La} \mathrm{CHLC}$ at $35^{\circ} \mathrm{C}$ and Zeta potential of the adsorbent with different $\mathrm{pH}$.
The kinetics results by linearized version of $\mathrm{F}$ adsorption on $\mathrm{Mg} / \mathrm{Fe} / \mathrm{La} \mathrm{CHLc}$ were described in Fig. 7(a) and (b), and the associated kinetic parameters were summarized in Table 2. The adsorption was fitting better with the pseudo second-order kinetics equation according to the $R^{2}$ and the theoretical adsorption capacity $\left(q_{\mathrm{e}, \mathrm{cal}}\right)$ values calculated from the pseudosecond-order model $\left(9.17 \mathrm{mg} \mathrm{g}^{-1}\right)$ were in agreement with the experimental adsorption capacity $\left(q_{\mathrm{e}, \exp }\right)$ values $\left(9.1 \mathrm{mg} \mathrm{g}^{-1}\right)$, both suggesting that the adsorption kinetic of fluoride on $\mathrm{Mg} /$ $\mathrm{Fe} / \mathrm{La}$ CHLc in water follows the pseudo-second-order model and implying that the adsorption process was chemisorption.

3.2.5 Adsorption isotherm. The adsorption isotherm of fluoride on $\mathrm{Mg} / \mathrm{Fe} / \mathrm{La} \mathrm{CHLc}$ was shown in Fig. 8. The Langmuir eqn (5) and Freundlich eqn (6) model were used to regressively stimulate the experimental adsorption isotherm data. The models can be expressed by the following formulas:

$$
\begin{gathered}
q_{\mathrm{e}}=\frac{q_{\mathrm{m}} b c_{\mathrm{e}}}{1+b c_{\mathrm{e}}} \\
q_{\mathrm{e}}=K_{\mathrm{F}} c_{\mathrm{e}}^{-n}
\end{gathered}
$$

where $c_{\mathrm{e}}$ is the equilibrium concentration $\left(\mathrm{mg} \mathrm{L}^{-1}\right)$ of fluoride, $q_{\mathrm{e}}$ is the amount of adsorbed $\left(\mathrm{mg} \mathrm{g}^{-1}\right) \mathrm{F}^{-}$on $\mathrm{Mg} / \mathrm{Fe} / \mathrm{La} \mathrm{CHLc}, q_{\mathrm{m}}$ is the maximum adsorption capacity $\left(\mathrm{mg} \mathrm{g}^{-1}\right)$ of fluoride and $b$ is the Langmuir adsorption constant $\left(\mathrm{L} \mathrm{mg}^{-1}\right)$ related to the adsorption-desorption energy. The constant $K_{\mathrm{F}}$ is correlated to the relative fluoride adsorption capacity of the $\mathrm{Mg} / \mathrm{Fe} / \mathrm{La} \mathrm{CHLc}$ $\left(\mathrm{mg} \mathrm{g}^{-1}\right)$, and $n$ is the adsorption intensity.

As showed in Fig. 8 and Table 3, the experiment data was in better agreement with the Langmuir model than the Freundlich model for fluoride adsorption on the $\mathrm{Mg} / \mathrm{Fe} / \mathrm{La} \mathrm{CHLc}$ in water according to the $R^{2}$, and the calculated value of $q_{\mathrm{m}}\left(q_{\mathrm{e}, \mathrm{cal}}\right.$, $59.98 \mathrm{mg}^{-1}$ ) from Langmuir model was close to the experimental adsorption capacity value $\left(q_{\text {e,exp}}, 58.79 \mathrm{mg} \mathrm{g}^{-1}\right)$. In addition, the Langmuir constant, $b$, with a positive value, indicated that the adsorption of fluoride on the adsorbent was a favorable adsorption system.

It was noted that the synthetic adsorbent $\mathrm{Mg} / \mathrm{Fe} / \mathrm{La} \mathrm{CHLc}$ had a higher adsorption capacity than most of other adsorbents reported, such as carbon-based, ${ }^{13,37}$ alumina-based, ${ }^{12,38}$ other metal oxide $\mathrm{e}^{\mathbf{1 4 3 9}}$ and layered double hydroxide ${ }^{32,40}$ materials (listed in Table 4). Although the adsorption capacity of some adsorbents like La modified seaweed was higher than that of $\mathrm{Mg} / \mathrm{Fe} / \mathrm{La} \mathrm{CHLC}$, the reaction time was longer and the preparation method was more complicated..$^{41}$ It was suggested that The $\mathrm{Mg} / \mathrm{Fe} / \mathrm{La} \mathrm{CHLc}$ is a potential new material as an adsorbent for $\mathrm{F}$ removal in terms of higher adsorption capacity or shorter operation time.

\subsection{Adsorption mechanism}

To further understand the adsorption mechanism of $\mathrm{F}$ on $\mathrm{Mg} /$ $\mathrm{Fe} / \mathrm{La}$ CHLc in water, the samples before and after fluoride adsorption were further investigated using SEM, $\mathrm{N}_{2}$ adsorptiondesorption, FT-IR and XPS analytical technique.

From Fig. 3c, it was found that the sheets of $\mathrm{Mg} / \mathrm{Fe} / \mathrm{La} \mathrm{CHLc}-$ F became more outstretched and the morphology look like petal 

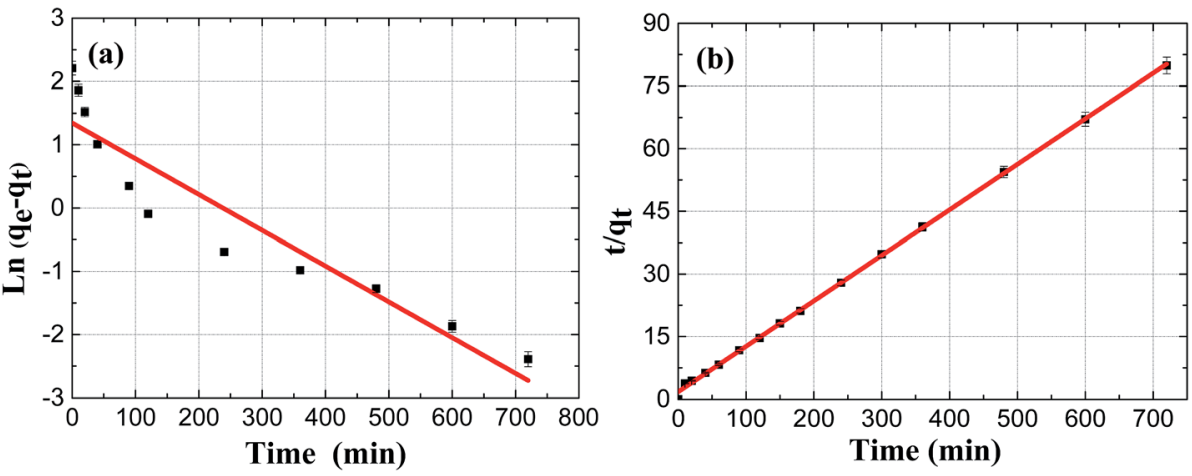

Fig. 7 Kinetics of fluoride adsorption onto Mg/Fe/La CHLc, linearized version and fitting with pseudo-first-order (a), linearized version and fitting with pseudo-second-order (b) (initial fluoride concentration, $5.2 \mathrm{mg} \mathrm{L}^{-1} ; \mathrm{pH}, 6.8 \pm 0.1$; temperature, $35^{\circ} \mathrm{C}$ ).

Table 2 Pseudo-first-order kinetics and pseudo-second-order kinetic model parameters for Mg/Fe/La CHLC

\begin{tabular}{|c|c|c|c|c|c|c|c|}
\hline \multirow[b]{2}{*}{ Materials } & \multirow[b]{2}{*}{$\begin{array}{l}q_{\mathrm{e}, \exp } \\
\left(\mathrm{mg} \mathrm{g}^{-1}\right)\end{array}$} & \multicolumn{3}{|c|}{ Pseudo-first-order kinetics } & \multicolumn{3}{|c|}{ Pseudo-second-order kinetics } \\
\hline & & $\begin{array}{l}q_{\mathrm{e}, \mathrm{cal}} \\
\left(\mathrm{mg} \mathrm{g}^{-1}\right)\end{array}$ & $\begin{array}{l}K_{1} \\
\left(\min ^{-1}\right)\end{array}$ & $R^{2}$ & $\begin{array}{l}q_{\mathrm{e}, \mathrm{cal}} \\
\left(\mathrm{mg} \mathrm{g}^{-1}\right)\end{array}$ & $\begin{array}{l}K_{2} \\
\left(\mathrm{~g} \mathrm{mg}^{-1} \min ^{-1}\right)\end{array}$ & $R^{2}$ \\
\hline $\mathrm{Ma} / \mathrm{Fe} / \mathrm{La} \mathrm{CHLc}$ & 9.1 & 8.55 & 0.0342 & 0.8759 & 9.17 & $0.68 \times 10^{-4}$ & 0.9994 \\
\hline
\end{tabular}

shaped, which was similar to the $\mathrm{Mg} / \mathrm{Fe} / \mathrm{La}$ HLc. This phenomenon can be descripted as the fluoride ions penetrating into the aperture of the sheets or adsorbed on the interlayer domain of $\mathrm{Mg} / \mathrm{Fe} / \mathrm{La} \mathrm{CHLc}$, which leads to the expansion of the platelet and the crystal structure reconstruction. The BET surface area of $\mathrm{Mg} / \mathrm{Fe} / \mathrm{La} \mathrm{CHLc}$ after adsorption decreased from $59.3 \mathrm{~m}^{2} \mathrm{~g}^{-1}$ to $27.9 \mathrm{~m}^{2} \mathrm{~g}^{-1}$, while the pore volume decreased from $0.347 \mathrm{~cm}^{3} \mathrm{~g}^{-1}$ to $0.249 \mathrm{~cm}^{3} \mathrm{~g}^{-1}$ (Table 1$)$. This phenomenon was due to that the fluoride effectively adsorbed onto the $\mathrm{Mg} / \mathrm{Fe} / \mathrm{La} \mathrm{CHLc}$ surface, indicating that surface adsorption

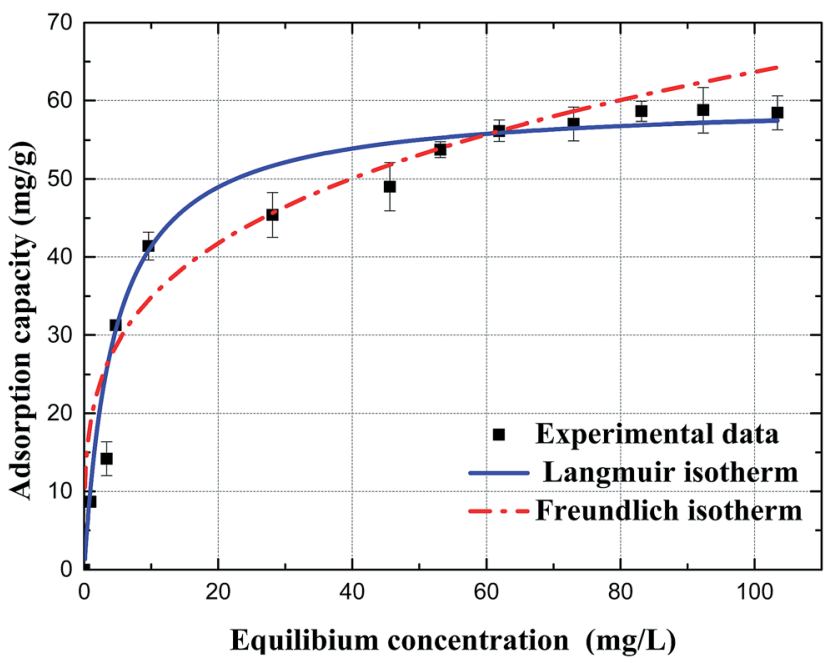

Fig. 8 Adsorption isotherms of fluoride on $\mathrm{Mg} / \mathrm{Fe} / \mathrm{La} \mathrm{CHLC}$, the data were fitted with the Langmuir model and Freundlich model $(\mathrm{pH}, 6.8 \pm$ 0.1 ; temperature, $35^{\circ} \mathrm{C}$, reaction time, $10 \mathrm{~h}$ ). played an important role during the fluoride adsorption by the hierarchically porous $\mathrm{Mg} / \mathrm{Fe} / \mathrm{La}$ CHLc.

The FT-IR spectra of the adsorbent before (b) and after fluoride adsorption (c) were given in Fig. 2. In comparison with virgin material, the $\mathrm{Mg} / \mathrm{Fe} / \mathrm{La} \mathrm{CHLc}$ after adsorption of fluoride appeared a sharp peak at $3696 \mathrm{~cm}^{-1}$, meanwhile, the $\mathrm{OH}$ group shifted and decreased. The results suggested that $\mathrm{OH}$ group involved in the fluoride adsorption reaction, which is consistent with the mechanism of the $\mathrm{Mg} / \mathrm{Fe} / \mathrm{La}$ mixed oxide for fluoride removal. ${ }^{15}$ The peak at $856 \mathrm{~cm}^{-1}$ (Fig. 3b), which was attributed to the La-O bond vibration, decreased after adsorption and a new peak $1384 \mathrm{~cm}^{-1}$ (Fig. 3c) appeared, indicating that interaction occurs between $\mathrm{La}-\mathrm{O}$ band and fluoride in the adsorption process, ${ }^{42}$ the specific mechanism of La for fluoride removal is further analysis by the XPS technique as follows.

XPS survey spectra and high-resolution XPS spectra of O1s, $\mathrm{La} 3 \mathrm{~d}$ of $\mathrm{Mg} / \mathrm{Fe} / \mathrm{La} \mathrm{CHLc}$ before and after fluoride loading were conducted to further study the mechanisms of fluoride adsorption on $\mathrm{Mg} / \mathrm{Fe} / \mathrm{La} \mathrm{CHLc}$ as shown in Fig. 9. It can be seen a new peak at $684.53 \mathrm{eV}$ appeared after adsorption of fluoride,

Table 3 The determined parameters and regression coefficients of Langmuir and Freundlich isotherms for fluoride adsorption on $\mathrm{Mg} / \mathrm{Fe} /$ La CHLC

\begin{tabular}{llc}
\hline Isotherm & Parameter & Value \\
\hline Langmuir & $q_{\mathrm{m}}\left(\mathrm{mg} \mathrm{g}^{-1}\right)$ & 59.98 \\
& $b\left(\mathrm{~L} \mathrm{mg}^{-1}\right)$ & 0.2217 \\
Freundlich & $R^{2}\left(\mathrm{mg}^{1-1 / n} \mathrm{~L}^{1 / n} \mathrm{~g}^{-1}\right)$ & 0.9806 \\
& $n$ & 19.04 \\
& $K^{2}$ & 0.2621 \\
& $R^{2}$ & 0.8774
\end{tabular}


Table 4 Comparison of the fluoride maximum adsorption capacity by $\mathrm{Mg}-\mathrm{Fe}-\mathrm{La} \mathrm{CHLC}$ with other reported adsorbents

\begin{tabular}{|c|c|c|c|c|}
\hline Adsorbents & $\mathrm{pH}$ & $\begin{array}{l}q_{\mathrm{e}} \\
\left(\mathrm{mg} \mathrm{g}^{-1}\right)\end{array}$ & $\begin{array}{l}\text { Equilibrium } \\
\text { time }\end{array}$ & References \\
\hline Bone char & $7-7.5$ & 4.81 & $6000 \mathrm{~min}$ & 37 \\
\hline $\begin{array}{l}\text { Single-walled } \\
\text { carbon nanotubes }\end{array}$ & 5 & 2.83 & $30 \mathrm{~min}$ & 13 \\
\hline Mesoporous alumina & 3 & 8.25 & $150 \mathrm{~min}$ & 38 \\
\hline $\begin{array}{l}\text { Hierarchical alumina } \\
\text { microspheres }\end{array}$ & 5.5 & 49.4 & $60 \mathrm{~min}$ & 12 \\
\hline $\begin{array}{l}\mathrm{Fe}-\mathrm{Al} \text { oxide-GO } \\
\text { composite }\end{array}$ & 7 & 27.75 & $120 \mathrm{~min}$ & 39 \\
\hline $\begin{array}{l}\mathrm{Mg}-\mathrm{Al}-\mathrm{La} \\
\text { hydrous oxide }\end{array}$ & 7 & 41.746 & $40 \mathrm{~min}$ & 14 \\
\hline $\mathrm{ZnCr}_{3}-\mathrm{NO}_{3}-\mathrm{LDH}$ & 6.8 & 31 & $120 \mathrm{~min}$ & 40 \\
\hline Li-Al-LDH & $6-7$ & 46.53 & $40 \mathrm{~min}$ & 32 \\
\hline La modified seaweed & 7 & 94.34 & $240 \mathrm{~min}$ & 41 \\
\hline $\mathrm{Mg} / \mathrm{Fe} / \mathrm{La} \mathrm{CHLc}$ & 6.8 & 59.34 & $100 \mathrm{~min}$ & This study \\
\hline
\end{tabular}

indicating that fluoride was effectively adsorbed onto the adsorbent, which matched the results of relative atoms amounts (\%) listed in the Table 5. The high-resolution spectra of the $\mathrm{O} 1 \mathrm{~s}$ and $\mathrm{La} 3 \mathrm{~d}$ for the $\mathrm{Mg} / \mathrm{Fe} / \mathrm{La} \mathrm{CHLc}$ before and after $\mathrm{F}$ adsorption in water were shown in Fig. 9b-e. The O1s can be deconvoluted into three components at about 529.35, 531.65 and $533.35 \mathrm{eV}$, assigning to $\mathrm{O}^{2-},-\mathrm{OH}$ and $\mathrm{H}_{2} \mathrm{O}$, respectively. ${ }^{43}$ The peaks of position O1s shifted to lower binding energy after fluoride adsorption, indicating that relevant interactions occurred between the $\mathrm{Mg} / \mathrm{Fe} / \mathrm{La} \mathrm{CHLc}$ and fluoride ion. In addition, the relative area ratio of $\mathrm{O}^{2-}$ decreased from $54.17 \%$ to $8.36 \%$, whereas the percentage of $-\mathrm{OH}$ increased from $42.13 \%$ to $91.64 \%$ (Table 6). This can be interpreted as the state of oxygen changing from $\mathrm{O}^{2-}$ to $-\mathrm{OH}$ during the rehydration process. As shown in Fig. 9(d) and (e), the intensity and relative area ratio of $3 d 3$ was markedly decreased after adsorption; meanwhile, two peaks appeared at 834.7 and $837.0 \mathrm{eV}$, which attributed to the $\mathrm{LaF}_{3}$.
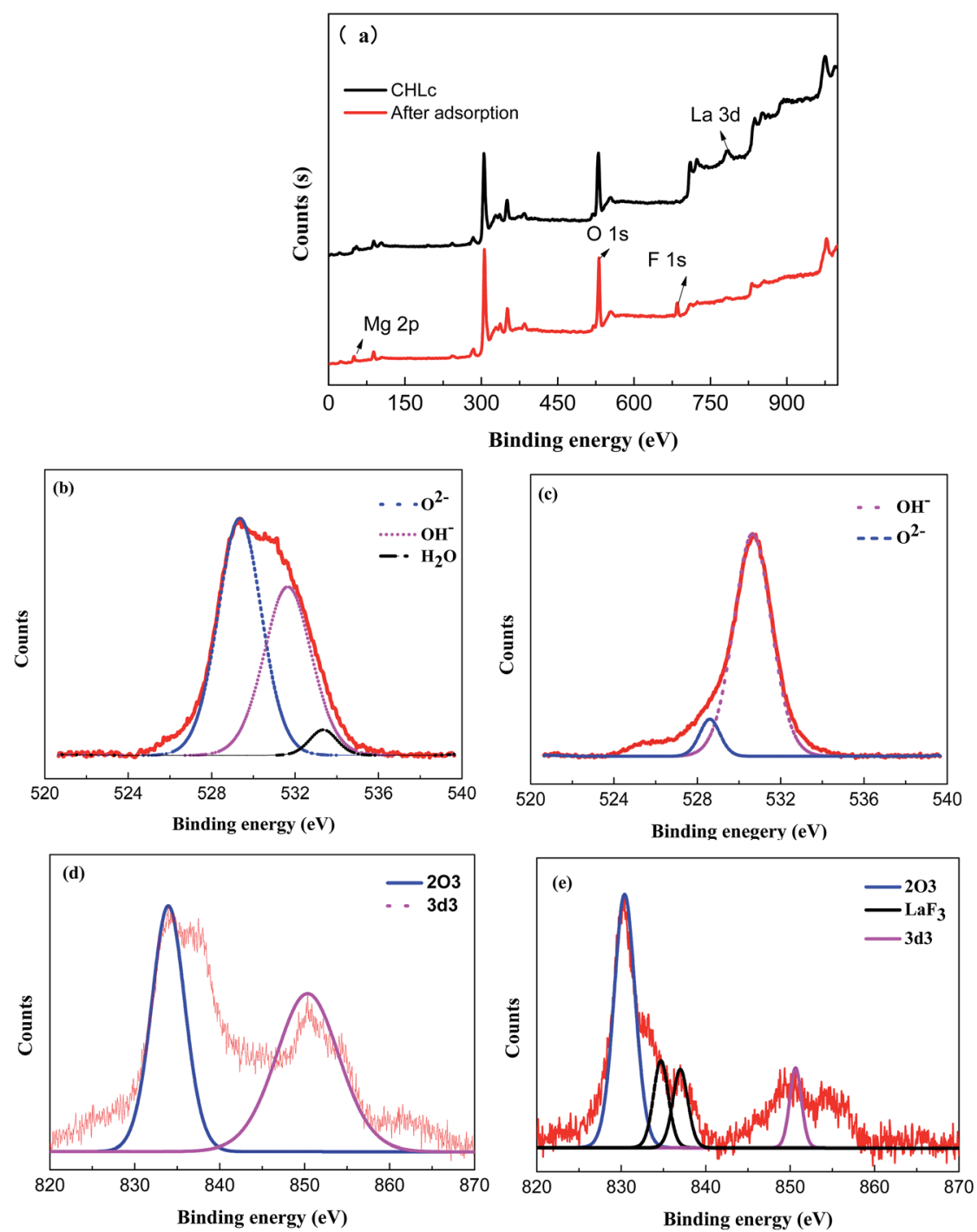

Fig. 9 XPS survey spectra of Mg/Fe/La CHLc before and after fluoride sorption (a); and high-resolution spectra of the O1s before adsorption (b), after adsorption (c), La $3 d$ before adsorption (d), after adsorption (e). 
Table 5 Atomic ratios of the Mg/Fe/La CHLc before and after fluoride adsorption

\begin{tabular}{lllll}
\hline Atomic ratios (\%) & O & C & F & Others \\
\hline $\mathrm{Mg} / \mathrm{Fe} / \mathrm{La} \mathrm{CHLc}$ & 51.18 & 19.13 & 0 & 29.69 \\
$\mathrm{Mg} / \mathrm{Fe} / \mathrm{La} \mathrm{CHLc-F}$ & 43.29 & 20.57 & 5.71 & 30.43 \\
\hline
\end{tabular}

Table 6 The percentage of $\mathrm{O}^{2-}$ and $-\mathrm{OH}$ distribution from the $\mathrm{O} 1 \mathrm{~s}$ peak of the $\mathrm{Mg} / \mathrm{Fe} / \mathrm{La} \mathrm{CHLC}$ before and after adsorption

\begin{tabular}{lllr}
\hline Sample & Peak & $\begin{array}{l}\text { Binding energy } \\
(\mathrm{eV})\end{array}$ & $\begin{array}{l}\text { Percent } \\
(\%)\end{array}$ \\
\hline $\mathrm{Mg} / \mathrm{Fe} / \mathrm{La} \mathrm{CHLc}$ & $\mathrm{O}^{2-}$ & 529.35 & 54.17 \\
$\mathrm{Mg} / \mathrm{Fe} / \mathrm{La} \mathrm{CHLc-F}$ & $-\mathrm{OH}$ & 531.65 & 42.13 \\
& $\mathrm{O}^{2-}$ & 528.6 & 8.36 \\
& $-\mathrm{OH}$ & 530.65 & 91.64
\end{tabular}

From the above analysis, the mechanism for fluoride removal by $\mathrm{Mg} / \mathrm{Fe} / \mathrm{La}$ CHLc was explained as follows in detail:

The containing carbonates and hydroxyl in the interlayer of $\mathrm{Mg} / \mathrm{Fe} / \mathrm{La} \mathrm{HLc}$ lost and layered double hydroxide decomposes into mixed metal oxides by thermal treatment (eqn (7)). The $\mathrm{Mg} / \mathrm{Fe} / \mathrm{La}$ CHLc can be rehydrated and incorporate fluoride ion in the interlayer to rebuild the original structure (eqn (8)). The fluoride ion incorporated into the interlayer of the $\mathrm{Mg} / \mathrm{Fe} / \mathrm{La} \mathrm{CHLc}$ by rebuilding of the original layered structure, called 'memory effect' of hydrotalcite, which was in accordance with the SEM results.

$$
\begin{aligned}
& {\left[\mathrm{Mg}_{1-x} \mathrm{Fe}_{0.9 x} \mathrm{La}_{0.1 x}(\mathrm{OH})_{2}\right]\left(\mathrm{CO}_{3}\right)_{\frac{x}{2}} \rightarrow} \\
& {\left[\mathrm{Mg}_{1-x} \mathrm{Fe}_{0.9 x} \mathrm{La}_{0.1 x}(\mathrm{O})_{1+\frac{x}{2}}\right]+\frac{x}{2} \mathrm{CO}_{2}+\mathrm{H}_{2} \mathrm{O}} \\
& {\left[\mathrm{Mg}_{1-x} \mathrm{Fe}_{0.9 x} \mathrm{La}_{0.1 x}(\mathrm{O})_{1+\frac{x}{2}}\right]+x \mathrm{~F}^{-}+\left(1+\frac{x}{2}+y\right) \mathrm{H}_{2} \mathrm{O} \rightarrow} \\
& {\left[\mathrm{Mg}_{1-x} \mathrm{Fe}_{0.9 x} \mathrm{La}_{0.1 x}(\mathrm{OH})_{2}\right](\mathrm{F})_{x}+x \mathrm{OH}^{-}}
\end{aligned}
$$

The active component of lanthanum oxide on the $\mathrm{Mg} / \mathrm{Fe} / \mathrm{La}$ CHLc presented complexation with hydroxyl during the rehydration process (eqn (9)). Due to that the hydroxyl compounds of lanthanum has strong affinity for fluoride, a complexation occurred between fluoride ion and lanthanum (eqn (10)). Moreover, fluoride and hydroxyl have similar hydrated ionic radius, which resulted in the competition between fluoride and hydroxyl (eqn (11)). It can be interpreted the surface complexation and ion exchange coordinated to lanthanum immobilized on $\mathrm{Mg} / \mathrm{Fe} / \mathrm{La} \mathrm{CHLc}$.

$$
\begin{gathered}
\mathrm{M}-\left(\mathrm{La}_{2} \mathrm{O}_{3}\right)_{n} \mathrm{La}_{2} \mathrm{O}_{3}+3 \mathrm{H}_{2} \mathrm{O} \rightarrow \mathrm{M}-\left(\mathrm{La}_{2} \mathrm{O}_{3}\right)_{n} 2 \mathrm{La}(\mathrm{OH})_{3} \\
\mathrm{M}-\left(\mathrm{La}_{2} \mathrm{O}_{3}\right)_{n} 2 \mathrm{La}(\mathrm{OH})_{3}+4 \mathrm{~F}^{-} \rightarrow \\
\mathrm{M}-\left(\mathrm{La}_{2} \mathrm{O}_{3}\right)_{n} 2 \mathrm{La}(\mathrm{OH}) \mathrm{F}_{2}+4 \mathrm{OH}^{-} \\
\mathrm{M}-\left(\mathrm{La}_{2} \mathrm{O}_{3}\right)_{n} 2 \mathrm{La}(\mathrm{OH}) \mathrm{F}_{2}+2 \mathrm{~F}^{-} \rightarrow \\
\mathrm{M}-\left(\mathrm{La}_{2} \mathrm{O}_{3}\right)_{n} 2 \mathrm{LaF}_{3}+2 \mathrm{OH}^{-}
\end{gathered}
$$

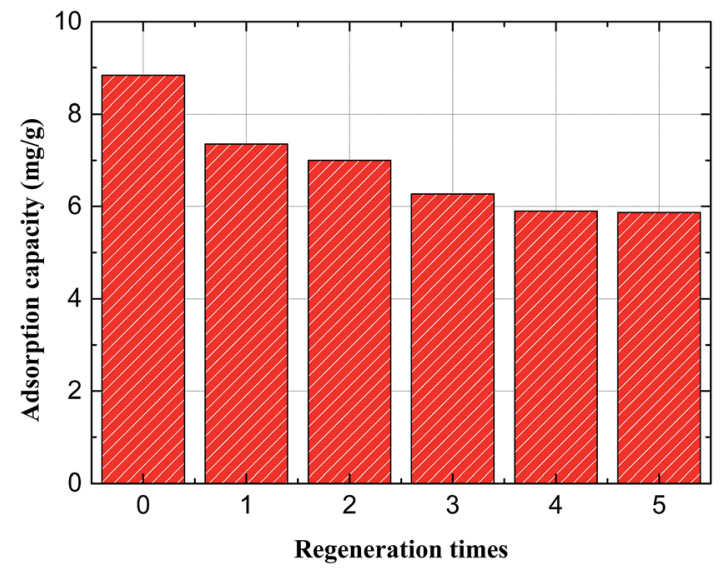

Fig. 10 Regeneration behaviors of $\mathrm{Mg} / \mathrm{Fe} / \mathrm{La} \mathrm{CHLc}$ by $0.1 \mathrm{M} \mathrm{Na}_{2} \mathrm{CO}_{3}$ (adsorbent dosage, $0.5 \mathrm{~g} \mathrm{~L}^{-1}$; initial fluoride concentration, $5.2 \mathrm{mg} \mathrm{L}^{-1}$; temperature, $35^{\circ} \mathrm{C}$; reaction time, $8 \mathrm{~h}$ ).

Therefore, the adsorption of fluoride on the $\mathrm{Mg} / \mathrm{Fe} / \mathrm{La} \mathrm{CHLc}$ was resulted from the chemisorption from the complexation of fluoride in water with the lanthanum on the surface of $\mathrm{Mg} / \mathrm{Fe} / \mathrm{La}$ CHLc, and also the surface adsorption by the porous structure and interlayer adsorption due to the "memory effect" of hydrotalcite.

\subsection{Desorption and regeneration}

To reduce the cost, environmental pollution and assess the reusability of the $\mathrm{Mg} / \mathrm{Fe} / \mathrm{La} \mathrm{CHLc}$, desorption and regeneration performances for re-use of the adsorbent were investigated. Desorption of the used $\mathrm{Mg} / \mathrm{Fe} / \mathrm{La}$ CHLc was performed in $0.1 \mathrm{M}$ $\mathrm{Na}_{2} \mathrm{CO}_{3}$ solution and separated by filtration, then calcined in the muffle furnace to regenerate the $\mathrm{Mg} / \mathrm{Fe} / \mathrm{La} \mathrm{CHLc}$. The adsorption capacity at different regeneration cycles were conducted up to five times and the results were shown in Fig. 10. The value of regeneration cycle 0 corresponds to adsorption amount of fresh $\mathrm{Mg} / \mathrm{Fe} / \mathrm{La} \mathrm{CHLc}$. With the increasing regeneration times, the adsorption capacity showed a slight decrease and then reached a plateau after 4 times regeneration. After 5 times of desorption-regeneration cycle, the adsorption capacity of fluoride still achieved a value as high as $5.9 \mathrm{mg} \mathrm{g}^{-1}$. In addition, it was also found that the adsorbent without calcination after $\mathrm{Na}_{2} \mathrm{CO}_{3}$ desorption can also showed a defluoridation performance, however, at a very low value (data not shown). This suggested that $\mathrm{CO}_{3}{ }^{2-}$ can replace the fluoride ion in the interlayer during the rehydration process, and re-build the structure of $\mathrm{Mg} / \mathrm{Fe} / \mathrm{La} \mathrm{HLc}$. Therefore, the $\mathrm{Mg} / \mathrm{Fe} / \mathrm{La}$ CHLc used as an adsorbent for defluoridation is relatively reversible and can be effectively regenerated via $\mathrm{Na}_{2} \mathrm{CO}_{3}$ desorption.

\section{Conclusions}

(1) In this work, the $\mathrm{Mg} / \mathrm{Fe} / \mathrm{La} \mathrm{CHLc}$ material was synthesized through a facile one-step hydrothermal method and calcination at $600{ }^{\circ} \mathrm{C}$. The $\mathrm{Mg} / \mathrm{Fe} / \mathrm{La} \mathrm{CHLc}$ has shown a high adsorption capacity to fluoride in water, and could be easily regenerated with an aqueous $\mathrm{Na}_{2} \mathrm{CO}_{3}$ solution, indicating that it could be 
a potential and effective adsorbent for removing fluoride from water.

(2) In the $\mathrm{Mg} / \mathrm{Fe} / \mathrm{La} \mathrm{HLc}$, the element of lanthanum played a significant role for the adsorption of fluoride in water.

(3) The adsorption of fluoride on the $\mathrm{Mg} / \mathrm{Fe} / \mathrm{La} \mathrm{CHLc}$ in water might be attributed to the chemisorption due to the complexation of fluoride in water with the lanthanum on the surface of $\mathrm{Mg} / \mathrm{Fe} / \mathrm{La}$ CHLc, besides of the surface adsorption and interlayer adsorption due to the "memory effect" of hydrotalcite.

(4) The adsorption followed the Langmuir isotherm and fitted to the kinetics of pseudo-second-order model the maximum adsorption capacity was $60 \mathrm{mg} \mathrm{g}^{-1}$ for fluoride.

\section{Acknowledgements}

The financial supports for this work from the National Natural Science Foundation of China under the project No. 51474167, No. 51604207 and No. 51674183 are gratefully acknowledged.

\section{References}

1 J. A. Camargo, Chemosphere, 2003, 50, 251-264.

2 M. G. Sujana, H. K. Pradhan and S. Anand, J. Hazard. Mater., 2009, 161, 120-125.

3 C. M. Kanno, R. L. Sanders, S. M. Flynn, G. Lessard and S. C. B. Myneni, Environ. Sci. Technol., 2014, 48, 5798-5807.

4 N. C. Lu and J. C. Liu, Sep. Purif. Technol., 2010, 74, 329-335.

5 L. H. Velazquez-Jimenez, R. H. Hurt, J. Matos and J. R. Rangel-Mendez, Environ. Sci. Technol., 2014, 48, 11661174.

6 Z. Amor, B. Bariou, N. Mameri, M. Taky, S. Nicolas and A. Elmidaoui, Desalination, 2001, 13, 215-223.

7 L. A. Richards, M. Vuachère and A. I. Schäfer, Desalination, 2010, 261, 331-337.

8 P. Wu, L. Xia, M. Dai, L. Lin and S. Song, Colloids Surf., A, 2016, 502, 66-73.

9 S. Chatterjee and S. De, Sep. Purif. Technol., 2014, 125, 223238.

10 A. Bhatnagar, E. Kumar and M. Sillanpää, Chem. Eng. J., 2011, 171, 811-840.

11 O. Kazak, A. Tor, I. Akin and G. Arslan, RSC Adv., 2016, 6, 86673-86681.

12 N. Xu, Z. Liu, Y. Dong, T. Hong, L. Dang and W. Li, Ceram. Int., 2016, 42, 15253-15260.

13 M. H. Dehghani, G. A. Haghighat, K. Yetilmezsoy, G. Mckay, B. Heibati, I. Tyagi, S. Agarwal and V. K. Gupta, J. Mol. Liq., 2016, 216, 401-410.

14 Z. Hussain, D. Li, X. Li and J. Kang, RSC Adv., 2015, 5, 4390643916.

15 J. Wang, D. Kang, X. Yu, M. Ge and Y. Chen, Chem. Eng. J., 2015, 264, 506-513.

16 S. Miyata, Clays Clay Miner., 1980, 28, 50-56.

17 J. Fan, Z. Xu and S. Zheng, J. Hazard. Mater., 2007, 139, 175177.
18 A. Elhalil, S. Qourzal, F. Z. Mahjoubi, R. Elmoubarki, M. Farnane, H. Tounsadi, M. Sadiq, M. Abdennouri and N. Barka, Emerging Contaminants, 2016, 2, 42-48.

19 K. Tomohito, O. Jumpei and Y. Toshiaki, J. Hazard. Mater., 2015, 293, 54-63.

20 T. Kameda, J. Oba and T. Yoshioka, J. Environ. Manage., 2017, 188, 58-63.

21 J. Das, P. B. Sairam, N. Baliarsingh and K. M. Parida, J. Colloid Interface Sci., 2007, 316, 216-223.

22 X. J. Zhang, G. S. Wang, W. Q. Cao, Y. Z. Wei, J. F. Liang, L. Guo and M. S. Cao, ACS Appl. Mater. Interfaces, 2014, 6, 7471-7478.

23 B. Kebede, A. Beyene, F. Fufa, M. Megersa and M. Behm, Appl. Water Sci., 2016, 6, 57-65.

24 D. Tang and G. Zhang, Chem. Eng. J., 2016, 283, 721-729.

25 J. Q. Chen, D. H. Yang, Y. Wei, J. H. Jiang, A. B. Ma and D. Song, Mater. Sci. Forum, 2015, 814, 118-124.

26 Y. Zhou, C. Yu and Y. Shan, Sep. Purif. Technol., 2004, 36, 8994.

27 S. Zhang, Y. Lu, X. Lin, X. Su and Y. Zhang, Appl. Surf. Sci., 2014, 303, 1-5.

28 K. Shimada, T. Shimoda, H. Kokusen and S. Nakano, Talanta, 2005, 66, 80-85.

29 X. L. Wu, L. Wang, C. L. Chen, A. W. Xu and X. K. Wang, J. Mater. Chem., 2011, 21, 17353-17359.

30 S. Fu, G. Fan, L. Yang, F. Li, S. Fu, G. Fan and L. Yang, Electrochim. Acta, 2015, 152, 146-154.

31 W. Xiang, G. Zhang, Y. Zhang, D. Tang and J. Wang, Chem. Eng. J., 2014, 250, 423-430.

32 T. Zhang, Q. Li, H. Xiao, H. Lu and Y. Zhou, Ind. Eng. Chem. Res., 2012, 51, 11490-11498.

33 T. Wu, L. Mao and H. Wang, RSC Adv., 2015, 5, 23246-23254.

34 D. Kang, X. Yu, S. Tong, M. Ge, J. Zuo, C. Cao and W. Song, Chem. Eng. J., 2013, 228, 731-740.

35 L. Lv, J. He, M. Wei, D. G. Evans and X. Duan, J. Hazard. Mater., 2006, 133, 119-128.

36 R. Bîrjega, O. D. Pavel, G. Costentin, M. Che and E. Angelescu, Appl. Catal., A, 2005, 288, 185-193.

37 E. M. Nigri, A. Bhatnagar and S. D. F. Rocha, J. Cleaner Prod., 2016, 142, 3558-3570.

38 S. G. Lanas, M. Valiente, E. Aneggi, A. Trovarelli, M. Tolazzi and A. Melchior, RSC Adv., 2016, 6, 42288-42296.

39 S. Kanrar, S. Debnath, P. De, K. Parashar, K. Pillay, P. Sasikumar and U. C. Ghosh, Chem. Eng. J., 2016, 306, 269-279.

40 P. Koilraj and S. Kannan, Chem. Eng. J., 2013, 234, 406-415. 41 Y. Yu, C. Wang, X. Guo and C. J. Paul, J. Colloid Interface Sci., 2015, 441, 113-120.

42 W. Zhang, J. Fu, G. Zhang and X. Zhang, Chem. Eng. J., 2014, 251, 69-79.

43 L. Po-I, C. Li-Ching, H. Chia-Hua, S. Hsin, L. Teh-Ming, H. Ren-Yang, C. Min-Chao and C. C. M. Ma, J. Colloid Interface Sci., 2014, 446, 352-358. 